\title{
STUDI RAGAM EKSTERIOR DAN KARAKTERISTIK REPRODUKSI BABI BALI
}

\author{
SUDIASTRA, I W. DAN K. BUDAARSA \\ Fakultas Peternakan, Universitas Udayana, Denpasar, Bali \\ e-mail: sudiastra.yok@gmail.com
}

\begin{abstract}
ABSTRAK
Penelitian ini bertujuan untuk mengetahui ragam eksterior dan karakteristik reproduksi babi bali yang masih bertahan hidup di Pulau Bali. Penelitian dilaksanakan selama 3 bulan mulai bulan Juli sampai September 2015. Data ini sangat diperlukan untuk menjelaskan mengapa babi bali sampai saat ini masih bisa bertahan di beberapa daerah di Bali. Penelitian menggunakan metode survei dan penentuan responden menggunakan teknik purposive sampling atau juggmental sampling dengan pertimbangan populasi babi bali di Bali tidak merata, hanya ada di beberapa kabupaten. Kabupaten yang dipilih adalah Klungkung, Karangasem dan Buleleng. Data yang diperoleh analisis secara deskriptif. Eksterior babi bali ada dua yaitu yang berwarna hitam dan berwarna hitam dengan belang putih pada perut dan keempat kakinya. Ciri khas babi bali yang utama adalah perutnya melengkung ke bawah (lordosis). Dimensi tubuh babi bali secara umum di ketiga daerah hampir sama dengan panjang badan riil kisarannya antara $97-137 \mathrm{~cm}$. Pengukuran berbasis tulang (standar) yaitu antara $80-97 \mathrm{~cm}$. Kalau dirataratakan dari ketiga tempat pengukuran maka tinggi babi bali sekitar $49 \mathrm{~cm}$. Dewasa kelamin pada umur 7-8 bulan, siklus birahi antara 15-20 hari, dikawinkan secara alami dengan jumlah anak 10 -14 ekor sekali beranak.
\end{abstract}

Kata kunci: babi bali, eksterior babi bali, pemeliharaan tradisional

\section{EKSTERIOR DIVERSITY AND REPRODUCTION CHARACTERISTIC STUDY OF BALI PIG}

\begin{abstract}
This research aims to know the variety of eksterior and characteristic reproduction of bali pig. It was carried out for 3 months from July until September 2015. This data is needed to explain the reason of bali pig remain the ability to survive in some areas in Bali. The experiment was using survey methods and respondents determination by using purposive sampling techniques or sampling juggmental. The selected districts were Klungkung, Karangasem and Buleleng. The data obtained was descriptively analyzed. Eksterior bali pig have two colours, black and stripe colour and black and black with white stripes on the stomach and its four legs. In general, the dimension of real Bali pig body measurement at those three districts were approximately between 97-137 cm. Bone standard measurement was between $80-97 \mathrm{~cm}$. Sexual maturity at the age of 7-8 months, estrus cycle between 15-20 days, mating normally with 10-14 piglets per birth.
\end{abstract}

Keywords: bali pig, bali pig eksterior, traditional maintenance

\section{PENDAHULUAN}

Masyarakat Bali, khususnya yang beragama Hindu yang hidup di pedesaan masih banyak yang memelihara babi bali. Dilihat dari keragaman kekayaan fauna Indonesia, babi bali merupakan plasma nutfah yang harus dilestarikan, oleh karena itu berbagai upaya untuk mempertahankan dan mengembangkan babi bali terus dilakukan. Keberadaan babi bali jangan sampai mengalami nasib seperti jalak bali atau harimau bali yang ditengarai punah.

Babi bali secara genetik pertumbuhannya lebih lambat dibandingkan dengan babi ras impor. Babi bali memerlukan waktu 12 bulan untuk mencapai berat badan $80 \mathrm{~kg}$, sedangkan babi ras impor hanya 5-6 bulan. Tetapi kelebihannya, babi bali adalah babi yang tahan menderita, lebih hemat terhadap air, masih mampu bertahan hidup walau diberi makan seadanya, sehingga sangat cocok dipelihara di daerah yang kering. Selain itu, babi bali sangat cocok dipelihara oleh para ibu rumah tangga di pedesaan di Bali sebagai celengan atau "tatakan banyu", karena pemeliharaannya bisa dilakukan secara sambilan dengan ransum tradisional sesuai dengan kemampuan peternak. 
Pemeliharaan babi di Bali masih mengandalkan ramsum tradisional yang komposisinya sangat beragam. Hal ini sangat tergantung dari daerah dimana babi tersebut dipelihara. Babi bali yang dipelihara oleh para peternak di pedesaan secara eksterior sangat beragam, baik dari warna bulu maupun ukuran dimensi tubuhnya. Informasi mengenai ragam eksterior babi bali yang dipelihara secara tradisional di Bali sampai saat ini belum ada. Peternak babi bali khususnya di pedesaan di Bali, tidak juga memahami secara pasti apakah babi yang dipeliharanya betul-betul babi bali atau atau babi keturunan babi ras. Hal ini mendorong dilakukannya penelitian ini, untuk mengetahui secara pasti eksterior babi bali yang ada saat ini dalam rangka memperkaya kasanah ilmu pengetahuan, khususnya dalam pelestarian babi bali sebagai plasma nutfah yang sudah semakin sedikit populasinya.

Tujuan penelitian ini adalah untuk mengetahui eksterior, dimensi tubuh dan karakteristik reproduksi babi bali yang masih dipelihara oleh peternak di Bali. Data ini sangat diperlukan untuk memastikan bagaimana sebenarnya eksterior dan dimensi tubuh babi bali yang sampai saat ini masih bisa bertahan di beberapa daerah di Bali.

Penelitian ini dikerjakan oleh tim yang mempunyai minat tinggi dalam penelitian ternak non ruminansia termasuk ternak lokal diantaranya babi bali. Tim mempunyai kapasitas dan kompetensi yang sangat memadai untuk mengerjakan penelitian ini berdasarkan pengalaman penelitian sebelumnya. Tim meyakini bahwa babi bali punya potensi untuk dikembangkan dan harus dilestarikan. Sampai saat ini kenyataan masih ada kantong-kantong lokasi yang bertahan memelihara babi bali dengan alasan bisa bertahan hidup dengan makanan seadanya, serta lebih tahan terhadap serangan berbagai penyakit.

Tujuan khusus dari penelitian ini adalah mengetahui secara pasti karakteristik babi bali dilihat dari eksterior, dimensi tubuh, dan informasi mengenai karakteristik reproduksinya, antara lain umur dewasa kelamin, lama birahi, siklus birahi, lama bunting, rata-rata jumlah kelahirannya. Dari informasi tersebut nantinya dapat dijadikan dasar untuk membuat model pengembangan babi bali sesuai dengan Roadmap Keilmuan Menuju Keunggulan Program Studi Peternakan Fakultas Peternakan (2011-2020).

\section{METODE PENELITIAN}

Penelitian ini menggunakan metode survei dan penentuan responden menggunakan teknik purposive sampling atau juggmental sampling dengan pertimbangan populasi babi bali di Bali tidak merata, hanya ada di beberapa kabupaten. Penelitian dilaksanakan se- lama 3 bulan mulai bulan Juli sampai September 2014 . Kabupaten yang dipilih adalah Klungkung, Karangasem dan Buleleng. Pemilihan kabupaten tersebut berdasarkan populasi babi bali di kabupaten tersebut paling tinggi dibandingkan dengan kabupaten lainnya.

Dari masing masing kabupaten diambil 20 peternak sebagai responden. Variabel yang diukur antara lain: warna bulu, tinggi tubuh, panjang tubuh, lingkar badan, panjang kepala, umur, panjang kaki depan, panjang kaki belakang dan panjang ekor. Dari aspek reproduksi akan dicari data mengenai: dewasa kelamin, umur pertama dikawinkan, lama birahi, tanda-tanda birahi, siklus birahi, jumlah puting susu, berat lahir, berat sapih dan umur sapih. Data yang diperoleh analisis secara deskriptif sehingga mampu memberi gambaran yang akurat tentang ragam eksterior dan karakteristik babi bali. Penelitian ini sangat mendukung RIP Unud, khususnya yang menyangkut ketahanan pangan dan Roadmap Penelitian Program Studi Peternakan, Fakultas Peternakan 2011-2020 dan Roadmap Grup Riset Kajian Nutrisi Ternak Nonruminansia. Pengambilan sampel dilakukan pada tiga kabupaten seperti Gambar 1
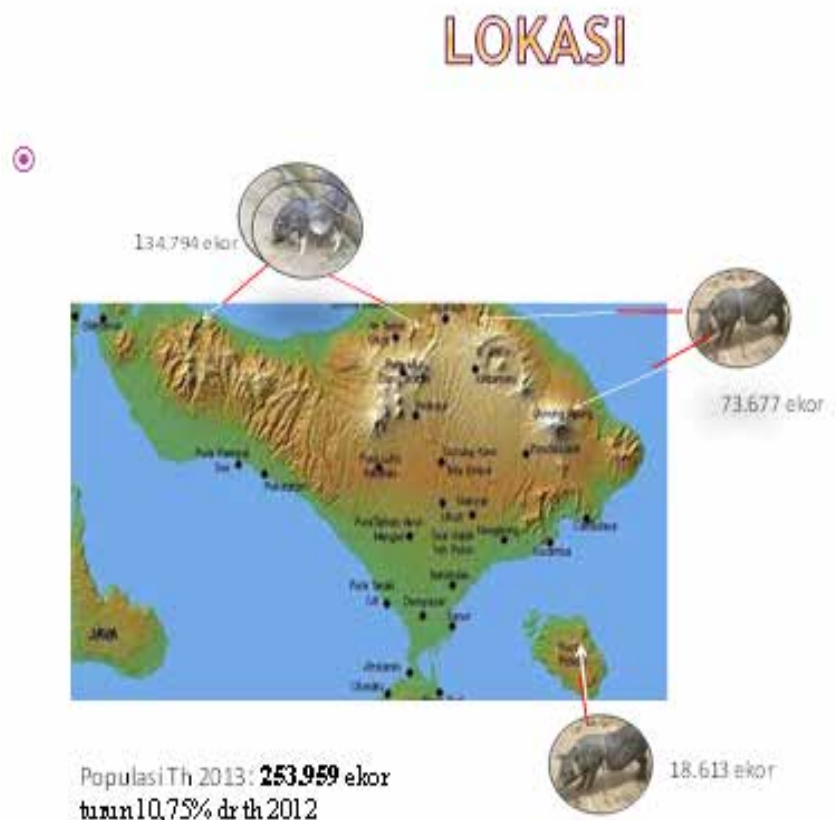

Gambar 1. Lokasi pengambilan sampel di tiga kabupaten dengan populasi babi bali paling tinggi

\section{HASIL DAN PEMBAHASAN}

\section{Sistem Pemeliharaan}

Sistem pemeliharaan babi bali di ketiga daerah sampel semuanya dengan sitem tradisional yakni mengikat dengan tali, kemudian diikatkan pada patok atau pohon (Gambar 2). Dengan demikian babi akan selalu kehujanan bila musim hujan, namun tidak kepanasan pada 
musim panas karena diikatkan di bawah pohon yang rindang. Sangat jarang yang membuat kandang beratap. Kalaupun ada, atap dibuat seadanya dari sisa-sisa bangunan atau terpal.

Di daerah Gerokgak ada yang memmelihara dalam kandang sederhana, tetapi babi tetap masih diikat. Alasannya agar babi lebih mudah datangani,jika talinya putus babi tidak kemana-mana.Dinding kandang ada yang terbuat dari batako, ada juga dari kayu atau bambu.Tempat makan ada yang menggunakan ember atau jerigen bekas. Ada juga yang menggunakan ban mobil bekas yang dibelah menjadi dua. Namun ada juga peternak yang secara khusus membuat tempat pakan dari cetakan beton. Tempat pakan dari beton ini sangat bagus, karena tidak mudah digeser-geser atau ditumpahkan oleh babi.

Kelemahan babi yang dipelihara dengan cara mengikat adalah babi selalu kotor, karena tanah selalu becek. Bahkan banyak yang berlumpur, dan babi akan berkubang disana. Babi dalam kondisi demikian rawan terinfeksi cacing dan parasit lainnya. Selain itu babi yang kakinya terikat sangat rawan patah kaki, terutama bila babi terkejut atau diganggu hewan lain.

Babi bali yang dipelihara secara tradisional diberi pakan seadanya. Jenis pakan yang diberikan sangat tergantung dari apa yang dimiliki oleh peternak saat itu. Namun demikian hampir di semua lokasi sampel, memberikan dedak padi atau polar sebagai pakan utama. Demikian juga batang pisang atau gedebong sudah menjadi makanan pokok babi bali. Ada juga yang memberikan bungkil kelapa (usam) jika mereka sedang membuat minyak kelapa.

Cara pemberian pakan ada yang mentah, ada juga yang diebus. Di Nusa Penida sebagian besar peternak merebus dulu makanan sebelum diberikan kepada babinya.

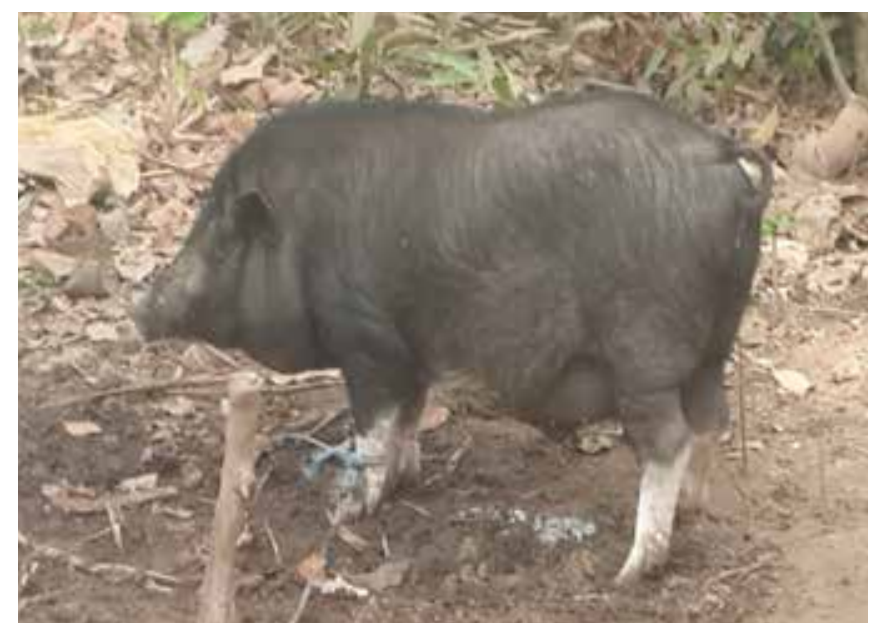

Gambar 2. Pemeliharaan babi bali secara tradisional dengan cara pengikat kakinya

\section{Eksterior}

Ekteriur babi bali ditandai oleh bentuk tubuh yang melengkung kebawah (lordosis). Bentuk ini ditemui di tiga daerah sampel, Klungkung, Karangasem dan Buleleng. Bentuk lordosis tersebut terjadi pada babi jantan dan pejantan (kaung ), induk (bangkung), babi dara maupun anak babi (kucit). Hanya saja pada babi penjantan melengkungnya tidak sekeras pada babi induk.

Warna babi bali di ketiga daerah sampel hanya ada dua, yaitu hitam dan hitam dengan belang putih pada perut dan kaki. Di kecamatan Nusa Penida Kabupaten Klungkung, warna babi bali dominan kombinasi warna hitam dengan belang putih pada kakinya (Gambar 3). Dari jauh kelihatan seolah memakai kaus kaki putih. Sebagian lagi belang putih pada perut bagian bawah, dan sebagian lagi ada yang melingkar di tubuh, tepatnya di belakang kepala.

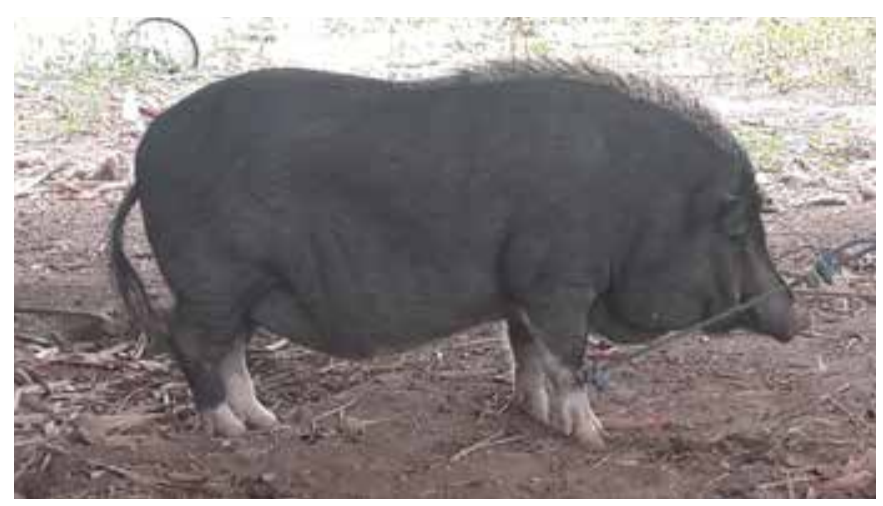

Gambar 3. Babi bali di Nusa Penida ada warna putih pata keempat kakinya.

Bulu pada garis punggung terutama pada bagian leher agak kasar dan sangat panjang, antara 6-8 $\mathrm{cm}$. Pada babi pejantan dan induk bulu tersebut lebih panjang, bahkan ada yang mencapai $10 \mathrm{~cm}$, dan merata dari depan ke belakang. Bulu punggung tersebut akan berdiri tegak ketika babi merasa terganggu. Misalnya seekor pejantan bulu punggungnya akan berdiri tegak bila diganggu oleh anjing, atau binatang lain. Demikian juga babi induk yang sedang beranak akan berdiri bulu punggungnya jika anaknya didekati.atau diambil.

\section{Dimensi Tubuh}

Dimensi tubuh babi bali secara umum jauh lebih kecil dibandingkan dengan babi ras. Panjang badan riil kalau diukur dari ujung cungur sampai ke pinggir paha belakang kisarannya antara 97-137 $\mathrm{cm}$. Pengukuran panjang riil ini untuk keperluan pembuatan kandang atau perlengkapan lain dalam penanganan babi hidup. Sedangkan kalau pengukuran berbasis tulang (standar) jauh lebih pendek yaitu antara 80-97 cm.

Tinggi bahu berkisar antara 48-57 cm, tinggi punggung antara 40-52 dan tinggi pinggang antara 
52-58 $\mathrm{cm}$. Kalau dirata-ratakan dari ketiga tempat pengukuran tersebut maka tinggi babi bali sekitar $49 \mathrm{~cm}$. Lingkar dada antara 90-136 cm, lingkar perut antara 95-136 cm dan lingkar pinggang 80-115 cm. Panjang kepala 20-25 cm, panjang daun telinga ratarata $10 \mathrm{~cm}$, dan panjang ekor $20-25 \mathrm{~cm}$.

Dimensi tubuh babi bali di tiga lokasi pengambilan sampel tidak jauh berbeda, baik babi dara, babi induk maupun pejantan, sedangkan yang agak menarik pada ukuran kepala. Babi bali yang ada di Gerokgak Buleleng mempunyai ukuran kepala yang sedikit lebih panjang dan agak runcing dibandingkan dengan yang ada di Nusa Penida maupun Kubu Karangasem. Ukuran dimensi tubuh babi bali di masing-masing lokasi disajikan pada Tabel 1, 2 dan 3. Panjang ekor babi bali berkisar antara 20-25 cm, sementara bulu pada punggung antara 3-8 $\mathrm{cm}$. Babi jantan dan induk mempunyai bulu lebih panjang dibandingkan babi dara. Bulu terpanjang berada tepat di belakang kepala.

Tabel.1. Dimensi tubuh babi bali di Kecamatan Nusa Penida Kabupaten Klungkung

\begin{tabular}{|c|c|c|c|c|}
\hline Dimensi tubuh & $\begin{array}{l}\text { Babi } \\
\text { dara }\end{array}$ & $\begin{array}{l}\text { Babi induk } \\
\text { (Bangkung) }\end{array}$ & $\begin{array}{l}\text { Babi } \\
\text { Pejantan } \\
\text { (Kaung) }\end{array}$ & Keterangan \\
\hline Panjang badan riil (cm) & 101 & 102 & 137 & \\
\hline $\begin{array}{l}\text { Panjang badan berbasis } \\
\text { tulang }(\mathrm{cm})\end{array}$ & 77 & 87 & 98 & $\begin{array}{l}\text { Diukur dari } \\
\text { ujung cungur } \\
\text { s/d pinggir paha } \\
\text { belakang }\end{array}$ \\
\hline Tinggi pundak (cm) & 48 & 49 & 56 & \\
\hline Tinggi perut $(\mathrm{cm})$ & 44 & 40 & 55 & \\
\hline Tinggi pinggang $(\mathrm{cm})$ & 52 & 52 & 56 & \\
\hline Lingkar dada $(\mathrm{cm})$ & 84 & 104 & 88 & \\
\hline Lingkar perut $(\mathrm{cm})$ & 104 & 95 & 80 & \\
\hline Lingkar pinggang (cm) & 101 & 80 & 80 & \\
\hline Panjang kepala (cm) & 22 & 21 & 23 & \\
\hline Panjang telinga $(\mathrm{cm})$ & 15 & 12 & 12 & \\
\hline Lebar telinga (cm) & 10 & 10 & 12 & \\
\hline Panjang ekor (cm) & 23 & 24 & 24 & \\
\hline $\begin{array}{l}\text { Panjang bulu punggung } \\
(\mathrm{cm})\end{array}$ & 6 & 6 & 8 & \\
\hline
\end{tabular}

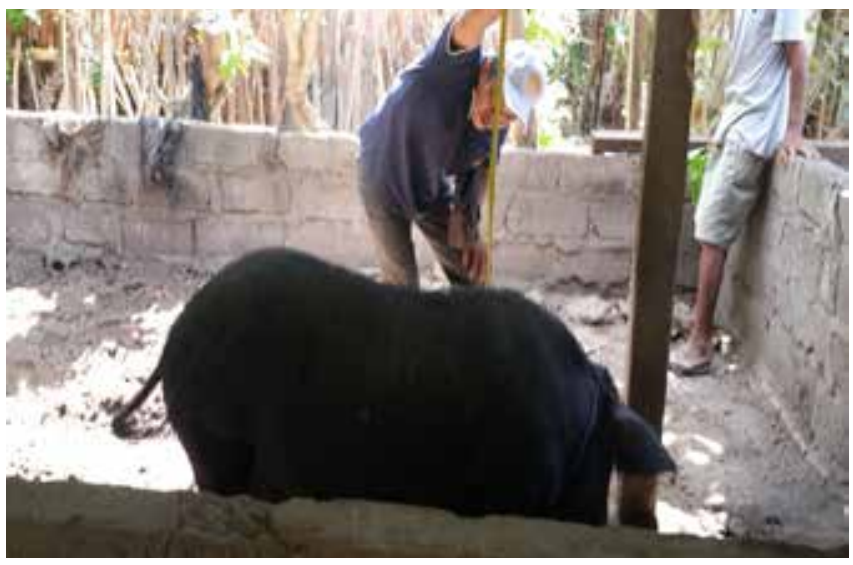

Gambar 4. Cara mengukur dimensi tubuh
Tabel 2. Dimensi tubuh babi bali di Kecamatan Kubu Kabupaten Karangasem

\begin{tabular}{|c|c|c|c|c|}
\hline Dimensi tubuh & $\begin{array}{l}\text { Babi } \\
\text { dara }\end{array}$ & $\begin{array}{l}\text { Babi induk } \\
\text { (Bangkung) }\end{array}$ & $\begin{array}{c}\text { Babi } \\
\text { Pejantan } \\
\text { (Kaung) }\end{array}$ & Keterangan \\
\hline Panjang badan riil $(\mathrm{cm})$ & 97 & 107 & 124 & \\
\hline $\begin{array}{l}\text { Panjang badan berbasis } \\
\text { tulang }(\mathrm{cm})\end{array}$ & 68 & 70 & 84 & $\begin{array}{l}\text { Diukur dari ujung } \\
\text { cungur s/d pinggir } \\
\text { paha belakang }\end{array}$ \\
\hline Tinggi pundak (cm) & 50 & 52 & 58 & \\
\hline Tinggi perut $(\mathrm{cm})$ & 48 & 50 & 57 & \\
\hline Tinggi pinggang $(\mathrm{cm})$ & 49 & 53 & 64 & \\
\hline Lingkar dada $(\mathrm{cm})$ & 80 & 85 & 102 & \\
\hline Lingkar perut $(\mathrm{cm})$ & 83 & 94 & 104 & \\
\hline Lingkar pinggang $(\mathrm{cm})$ & 82 & 106 & 106 & \\
\hline Panjang kepala (cm) & 20 & 21 & 22 & \\
\hline Panjang telinga $(\mathrm{cm})$ & 10 & 12 & 13 & \\
\hline Lebar telinga $(\mathrm{cm})$ & 9 & 10 & 10 & \\
\hline Panjang ekor $(\mathrm{cm})$ & 21 & 25 & 24 & \\
\hline Panjang bulu punggung & 5 & 6 & 8 & \\
\hline
\end{tabular}

Tabel 3. Dimensi tubuh babi bali di Kecamatan Gerokgak Kabupaten Buleleng

\begin{tabular}{|c|c|c|c|c|}
\hline Dimensi tubuh & $\begin{array}{l}\text { Babi } \\
\text { dara }\end{array}$ & $\begin{array}{l}\text { Babi induk } \\
\text { (Bangkung) }\end{array}$ & $\begin{array}{c}\text { Babi } \\
\text { Pejantan } \\
\text { (Kaung) }\end{array}$ & Keterangan \\
\hline Panjang badan riil (cm) & 98 & 107 & 150 & \\
\hline $\begin{array}{l}\text { Panjang badan berbasis } \\
\text { tulang }(\mathrm{cm})\end{array}$ & 65 & 68 & 103 & $\begin{array}{l}\text { Diukur dari } \\
\text { ujung cungur } \\
\text { s/d pinggir paha } \\
\text { belakang }\end{array}$ \\
\hline Tinggi pundak (cm) & 50 & 55 & 63 & \\
\hline Tinggi perut $(\mathrm{cm})$ & 47 & 54 & 59 & \\
\hline Tinggi pinggang (cm) & 49 & 55 & 60 & \\
\hline Lingkar dada $(\mathrm{cm})$ & 82 & 92 & 135 & \\
\hline Lingkar perut $(\mathrm{cm})$ & 86 & 115 & 105 & \\
\hline Lingkar pinggang $(\mathrm{cm})$ & 85 & 95 & 110 & \\
\hline Panjang kepala $(\mathrm{cm})$ & 20 & 21 & 20 & \\
\hline Panjang telinga $(\mathrm{cm})$ & 12 & 11 & 17 & \\
\hline Lebar telinga $(\mathrm{cm})$ & 9 & 10 & 12 & \\
\hline Panjang ekor (cm) & 20 & 23 & 20 & \\
\hline $\begin{array}{l}\text { Panjang bulu punggung } \\
(\mathrm{cm})\end{array}$ & 3 & 3 & 6 & \\
\hline
\end{tabular}

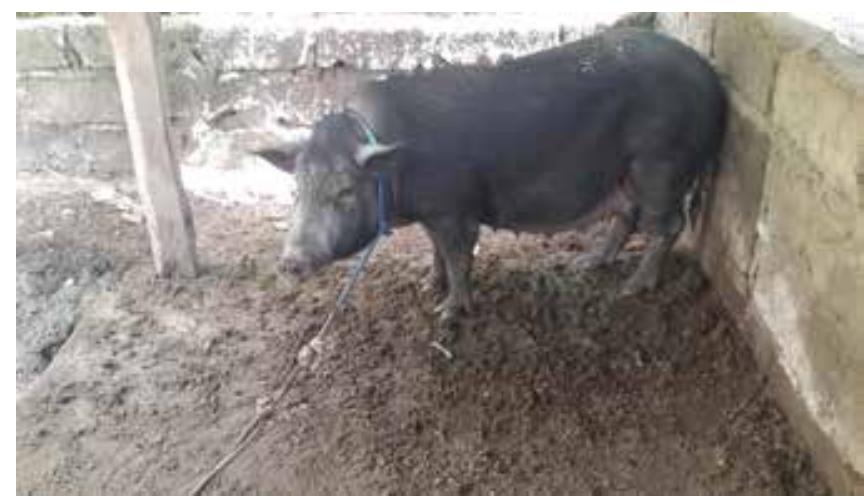

Gambar 5. Induk muda, bunting pertama saat usia bunting 2 bulan 
Tabel 4. Karakteristik reproduksi babi bali ditiga kecamatan di Bali

\begin{tabular}{|c|c|c|c|}
\hline \multirow{2}{*}{$\begin{array}{c}\text { Karakteristik } \\
\text { Reproduksi }\end{array}$} & \multicolumn{3}{|c|}{ Kecamatan } \\
\hline & Nusa Penida & Kubu & Gerokgak \\
\hline Babi dara dewasa kelamin (bulan) & 6 & 7 & 6 \\
\hline $\begin{array}{l}\text { Induk muda pertama dikawinkan } \\
\text { umur (bulan) }\end{array}$ & 8 & 8 & 8 \\
\hline Tanda-tanda birahi & $\begin{array}{l}\text { Gelisah, tidak mau makan, } \\
\text { vulvanya membengkak, diam bila } \\
\text { punggunya di pegang }\end{array}$ & $\begin{array}{l}\text { Gelisah, tidak mau makan, } \\
\text { vulvanya membengkak, diam bila } \\
\text { punggunya di pegang }\end{array}$ & $\begin{array}{c}\text { Gelisah, tidak mau makan, } \\
\text { vulvanya membengkak, diam bila } \\
\text { punggunya di pegang }\end{array}$ \\
\hline Lama birahi (hari) & 3 & 3 & 3 \\
\hline Siklus birahi (hari) & 15 & 16 & 15 \\
\hline Dikawinkan pada birahi ke & 2 & 2 & 2 \\
\hline Cara mengawinkan & alami & alami & Alami \\
\hline Ongkos mengawinkan (Rp) & 1 ekor anak & 70 & 50 \\
\hline Jumlah puting susu & $10-14$ & $12-14$ & $12-14$ \\
\hline $\begin{array}{l}\text { Jumlah anak perkelahiran } \\
\text { (litter size) }\end{array}$ & 10 & $10-14$ & $10-14$ \\
\hline
\end{tabular}

\section{Karakteristik Reproduksi}

Dewasa kelamin abi betina calon induk pada umur 6-7 bulan. Tetapi peternak tidak mau mengawinkan dengan alasan belum cukup umur.Induk muda dikawinkan pada umur 8 bulan.Babi induk ketika birahi menunjukan tanda-tandaantara lain: gelisah, tidak mau makan, vulvanya membengkak, diam bila punggunya di pegang dan mengeluarkan air liur.

Lama babi betina birahi adalah tiga hari, bila tidak dikawinkan akan birahi kembali dalam selang waktu 15-20 hari. Selang waktu ini disebut siklus birahi. Umumnya peternak mengawinkan babinya pada hari kedua setelah menunjukkan gejala birahi.Mereka tidak mau mengawinkan pada birahi pertama dengan alasan supaya yakin terjadi pembuahan. Semua peternak babi bali mengawinkan babi iduknya dengan cara alami. Belum ada yang menggunakan kawin suntik atau IB.

Biaya mengawinkan induk babi berbeda-beda antara satu daerah dengan daerah llainnya.Di Nusa Penida ongkos penjantan dibayar dengan satu ekor anak. Pemilik pejantan akan menerima ongkos beruoa anak babi ketika anak babi sudah disapih yakni pada umur kurang lebih 2-3 bulan. Di Kecamatn Kubu Karangasem ongkos pejantan dibayar langsung dengan uang bervariasi dari Rp 50.000; - Rp 70.000, tergantung jarak. Demikian juga di Kecamatan Gerokgak Buleleng ongkosnya antara Rp. 40.000-50.000. Bahkan ada peternak yang membayar hanya Rp 25.000: mereka umumnya masih keluarga dekat pemilik pejantan. Jadi sifatnya kekeluargaan, pemilik pejantan lebih mengedepankan unsur memberi bantuan.

Jumlah anak dalam satu kali kelahiran (litter size) beragam antara satu daerah dengan daerah lainnya. Di Nusa Penida paling banyak litters sizenya 10 ekor. Di daerah Kubu dan Gerokgak Buleleng bisa mencapai 14 ekor. Hal ini mungkin ada hubungannya dengan jumlah puting susu induk. Di Nusa Penida sebagian besar induk babi mempunyai puting susu hanya 10 buah. Sedangkan di Kubu dan Gerokgak sebagian besar 14 buah atau 7 pasang. Sebenarnya makin banyak puting susu semakin baik induk tersebut, sehingga jika anaknya 10 ekor, maka ada cadangan puting susu untuk anak-anaknya yang kalah berebut.

\section{SIMPULAN}

Dilihat dari eksteriornya babi bali ada dua yaitu yang berwarna hitam dan berwarna hitam dengan belang putih pada perut dan keempat kakinya. Ciri khas babi bali yang utama adalah perutnya melengkung ke bawah (lordosis). Dimensi tubuh babi bali secara umum di ketiga daerah hampir sama dengan Panjang badan riil kisarannya antara 97-137 $\mathrm{cm}$. Sedangkan kalau pengukuran berbasis tulang (standar) jauh lebih pendek yaitu antara 80-97 cm. Kalau dirata-ratakan dari ketiga tempat pengukuran maka tinggi babi bali sekitar $49 \mathrm{~cm}$. Dewasa kelamin pada umur 7-8 bulan, siklus birahi antara 15-20 hari, dikawinkan secara alami dengan jumlah anak 10 -14 ekor sekali beranak.

\section{DAFTAR PUSTAKA}

Bali dalam Angka. 2013. Badan Pusat Statistik Provinsi Bali. Penerbit BPS Provinsi Bali.

Budaarsa K. 2002. Survei Kebutuhan Babi Guling di Kota Denpasar. Laporan Penelitian. DIK. Universitas Udayana.

Budaarsa K. 2006. Survei Kebutuhan Babi Guling di Kabupaten Badung. Laporan Penelitian. DIK. Universitas Udayana.

Budaarsa K. 1997. Kajian Penggunaan Rumput Laut dan Sekam Padi sebagai Sumber Serat dalam Ransum untuk Menurunkan Kadar Lemak Karkas dan Kolesterol Daging Babi. Disertasi Program Pascasarjana Institut Pertanian Bogor. 
Budaarsa K. 2011.Nama Nama Latin Hewan.Denpasar. Udayana University Press.

Budaarsa K. 2012. Babi Guling Bali dari Beternak Kuliner hingga Sesaji. Penerbit Buku Arti, Denpasar.

Budaarsa K. dan I N. A. T. Ariana, K.M. Budiasa dan P.A. Astawa. 2013. Hijuan Pakan Babi dan Cara Penggunaannya Pada Peternakan Babi Tradisonal di Provinsi Bali. Disampaikan pada Seminar Nasional II Himpunan Ilmuwan Tumbuhan Pakan Indonesia (HIPTI)di Denpasar 28-29 Juni 2013.

Budaarsa K. dan K. Mangku Budiasa. 2013. Jenis Hewan Upakara dan Upaya Pelestariannya. Makalah disampaikan pada seminar hewan upakara Fakultas Peternakan Universitas Udayana, Denpasar 29 Oktober 2013.

Budaarsa K. 2014. Potensi Ternak Babi dalam Menyumbangkan Daging di Bali. Makalah

disampaikan pada Seminar Nasional Ternak Babi di Fakultas Peternakan Universitas Udayana, 5 Agustus 2014.

Hartadi,H., S Reksohadiprodjo dan A. D. Tillman. 1990. Tabel Komposisi Pakan untuk Indonesia. Yogyakarta, Gajah Mada University Press.

Mansyur, U., H.Tanuwiria dan D. Rusmana. 2006. Eksplorasi Hijauan Pakan Kuda dan Kandungan Nutrisinya.Universitas Padjadjaran Bandung.

Sihombing, D.T.H. 2006. Ilmu Ternak Babi. Yoyakarta, Gajahmada Univesity Press.

Sugiono. 2007. Statistik untuk Penelitian, Alfabeta Bandung. 